\title{
Phenotypic variations of endophytic bacteria associated with carob tree (Ceratonia siliqua L.)
}

\author{
Ibrahim Konate ${ }^{1}$, Annick Koulibaly ${ }^{1}{ }^{*}$, Mathurin Koffi ${ }^{1}$, Amina Sorouri ${ }^{2}$, El Bekkay Berraho ${ }^{2}$, \\ Abdelkarim Filali-Maltouf ${ }^{2}$ \\ ${ }^{1}$ Unité de formation et de Recherche en Agroforesterie et en Environnement, Université Jean Lorougnon Guédé, BP 150 Daloa, Côte d'Ivoire \\ ${ }^{2}$ Faculty of Sciences, Laboratory of Microbiology and Molecular Biology, University Mohammed V-Agdal, Rabat, Morocco
}

\section{Email address:}

konatibrahim@yahoo.fr (I. Konate), koulannick@yahoo.fr (A. Koulibaly)

\section{To cite this article:}

Ibrahim Konate, Annick Koulibaly, Mathurin Koffi, Amina Sorouri, El Bekkay Berraho, Abdelkarim Filali-Maltouf. Phenotypic Variations of Endophytic Bacteria Associated with Carob Tree (Ceratonia Siliqua L.). American Journal of Life Sciences. Vol. 2, No. 5, 2014 , pp. $325-332$. doi: $10.11648 /$ j.ajls.20140205.22

\begin{abstract}
We aimed to characterize 83 endophytic bacteria isolated from roots (73 isolates coded IRC) and epicotyls (11 isolates coded IEC) of young Carob (Ceratonia siliqua L.) seedlings. These seedlings were obtained from seeds collected in several regions in Morocco. 30 IRC and 4 IEC were selected on the basis of PCR-Pep for the further analyses. All the strains exhibited a wide tolerance to $\mathrm{NaCl}$ and $30 \%$ tolerated well concentration up to $11 \% \mathrm{NaCl}$. Strains showed also a wide tolerance to the variable $\mathrm{pH} .60 \%$ of strains grew well at $\mathrm{pH} 4$. Most of the strains were resistant to different antibiotics but were sensitive to kanamycin and tetracycline. The strains showed a resistance to heavy metals except mercury chloride that was toxic at a low concentration $50 \mu \mathrm{g} . \mathrm{ml}-1$. According to their phenotypical features, the associative bacteria were very similar to eight symbiotic bacteria previously identified by Missbah in 1996 and used in this work.
\end{abstract}

Keywords: Isolation, Associative Endophytic Bacteria, Phenotypic Characterization, Managed Ecosystem

\section{Introduction}

In managed ecosystems, plant-associated bacteria play a key role in host adaptation to a changing environment $[1,2$, 3]. Microbial endophytic species are present in a wide range of plant species and reside either within cells, in the intercellular space or in the vascular system of plant [4].

The term endophyte was defined by De Bary [5] cited by Stone [6] and refers to mycotic flora that inhabits the interior of plant tissues. This term was then applied to bacteria and was the subject of several conceptual definitions [7]. In general, this term includes all microorganisms that are able to colonize, during some portion of their life cycle, the inner tissues of plants without causing any apparent damage to the host [8].

Interaction between plant and beneficial bacteria can have a profound effect on crop health and yield [3]. Bacteria known as Plant Growth-Promoting Rhizobacteria (PGPR) [9] that colonize root, can enhance shoot emergence and stimulate plant growth through production of auxins, gibberellins and cytokinins [10], induce plant defense mechanisms, produce antibiotic, out-compete pathogens and improve soil structure [11-13, 14].

The faculty to infect and colonize roots has been considered the major factor that determine inoculum efficacy both for crop yield enhancement and for disease control [15]. Root colonization by endophytic bacteria occurs preferentially through the natural fissures resulting from the emergence of lateral root like lateral root cracks (LRCs) or on the root surface and root tips [16].

The flavonoids (naringenin and daizein) were found to stimulate significantly the LRC colonization of Wheat and Arabidopsis thaliana by Azorhizobium caulinodans ORS571, by Azospirillum and by Herbaspirillum [16, 17]. Inside the plant tissues, bacteria form a large intercellular infection pockets in which the endophyte divide, develop infection threads and interchange with host [18].

The potential of PGPR to fix atmospheric nitrogen and promote plant growth has renewed the interest in such associations. Patriquin et al. [19] demonstrated hormonal effects, biological nitrogen fixation and interference in other processes of the nitrogen assimilation of some bacteria associated with plants. For several uninoculated soil grown Gramineae, $15 \mathrm{~N}$-enriched tracer studies have shown that 
microbial communities can fix substantial amounts of atmospheric N2 [20, 21]. The activity of the enzyme Nitrogenase was detected, in vitro culture, inside the Carob roots and bourgeons [22]. The identification of diazotrophic bacteria responsible for $\mathrm{N}$-gain is important for agricultural applications well as for understanding ecosystem processes $[23,24]$. Non-rhizobial endophytic diazotrophs like Azoarcus spp., Gluconacetobacter diazotrophicus, Herbaspirillum spp. and Burkholderia spp. have been isolated respectively from kallar grass, sugarcane, rice and vine [25, 26, 27]. Recently, several researches demonstrated other behaviour of symbiotic rhizobia such as natural endophytes that can colonize interior tissues and increase the productivity of many leguminous or non-leguminous plants [28-32, 33, 34]. In Côte d'Ivoire, first producer of cocoa to the world, cultivation practices increase cocoa farms degradation [35] and cocoa diseases. Indigenous microorganisms of cocoa tree were identified as well as antagonist against Phytosphthora sp, the causal agent of black pod disease [36].

Carob (Ceratonia siliqua L.) is an endemic leguminous tree of the Mediterranean region [37, 38]. It presents a great industrial and pharmaceutical importance [39, 40, 41]. Actually, Carob tree gain much attention since it is considered as an important component for re-vegetation and environmental conservation [39, 42].

In a previous investigation, we have observed from sterile sectioned parts of young seedlings used in vitro culture, the emergence of some bacterial strains. We were curious to know if endophytic bacteria can reside in internal tissues of Carob. In our knowledge, no investigation has concerned the finding of endophytic bacteria associated with Carob tree. Thus, the aims of the present work are: (i) to isolate endophytic bacteria from vegetative organs of Carob originating from seeds collected in different regions of Morocco; (ii) to characterize representative's strains by phenotypic features selected on the basis of PCR-Pep.

\section{Material and Methods}

\subsection{Plant Material}

The seeds used in this work were obtained from pods collected from 11 regions of Morocco: Taourirt, Al Houceima, Taounate, Aïn Safa, Akchort, Demnate, Ouazzane, Sidi Bou Othmane, Essaouira, Tetouan and Ouad Lou. Each collection of seeds was referred to its original region as a separate accession. Soil sample were also collected in each region.

Seeds were scarified by $\mathrm{H} 2 \mathrm{SO} 4$ at $95 \%$. After the germination of seeds on sterile water agar $(0.7 \% \mathrm{w} / \mathrm{v})$, plates were incubated at $28^{\circ} \mathrm{C}$ in obscurity. The young seedlings were transferred in pots containing soil of the same origin then placed in a growth chamber.

\subsection{Isolation of Endophytic Bacteria}

After six months of cultivation (Figure 1 a), roots and epicotyls of young Carob seedlings were used for bacterial isolation.

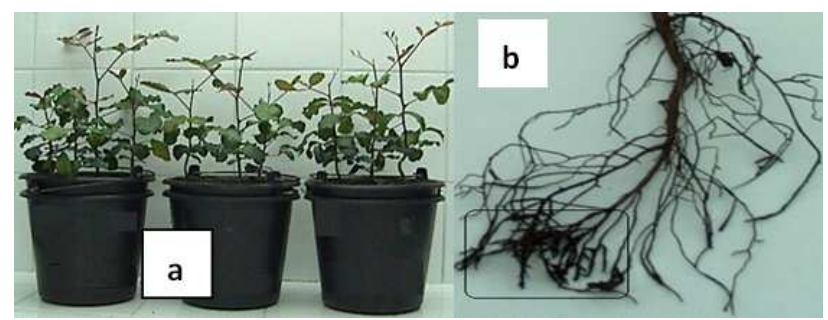

Figure 1. Carob seedlings in cultivation (a), roots of young Carob tree, (b) filament and finger (rectangle) forms.

\subsubsection{Isolation from Roots}

The roots of Carob tree were not uniform. We have found filament and finger forms (Figure $1 \mathrm{~b}$ ). Finger forms of roots, was washed several times with sterile water, sterilized with $0.1 \% \mathrm{HgCl} 2$ for $5 \mathrm{~min}$ under vigorous shaking, and washed thoroughly with sterile water and then ground with $1 \mathrm{~mL}$ of pure water. The mixed tissue $(0.5 \mathrm{~mL})$ was spotted on YEM medium [43] and incubated at $28^{\circ} \mathrm{C}$.

\subsubsection{Isolation from Epicotyls}

Epicotyls were successively treated with SDS (0.01\%) for 2 $\mathrm{h}$, with $\mathrm{HgCl} 2(0.2 \%)$ for $10 \mathrm{~min}$ then washed with sterile water. Epicotyls portions of $0.5 \mathrm{~cm}$ to $1 \mathrm{~cm}$ were sectioned, transferred on sterile water agar plates $(0.7 \% \mathrm{w} / \mathrm{v})$ then incubated at $28^{\circ} \mathrm{C}$.

\subsection{Phenotypic Features}

30 IRC and 4 IEC strains representing the various PCR-Rep groups and also 8 strains nodulating Carob (RCM) previously identified by Missbah et al. [44] were used to realize further analyses.

All tests were carried out on YEM agar plates. Petri dishes containing YEM medium were subdivided into squares and each square was inoculated with $10 \mu$ l of YEM broth bacterial culture. After 7 days of incubation at $28^{\circ} \mathrm{C}$, bacterial growth was compared to the controls. Two replication tests were done for each treatment.

\subsubsection{Salt Tolerance}

It was conducted on agar plates at variable concentrations ranging from 1 to $12 \% \mathrm{NaCl}(\mathrm{w} / \mathrm{v})$.

\subsection{2. pH Resistance}

Tolerance to $\mathrm{pH}$ was tested on YEM plates set at different $\mathrm{pH}$ values, using the buffers MES (20mM) (SIGMA) for $\mathrm{pHs}$ ranging between 5.5 and 6.7, and MOPS (20 mM) (SIGMA) for $\mathrm{pHs}$ ranging between 6.7 and 7.9. The medium was buffered with $\mathrm{HCl}$ for $\mathrm{pH}$ values lower than 5.5 and with $\mathrm{NaOH}$ for $\mathrm{pH}$ values between 8 and 10 .

\subsubsection{Antibiotics Tolerance}

The intrinsic resistance of strains was determined on solid YEM medium containing the following filter sterilized antibiotics: ampicillin, chloramphenicol, erythromycin, kanamycin, nalidixic acid, rifampicin, spectinomycin, streptomycin and tetracycline at variable concentrations ranging from 10 to $100 \mu \mathrm{gml}-1$. 


\subsubsection{Heavy Metal Resistance}

The resistance of strains to heavy metals was also determined on solid YEM medium. The stock solutions of metals were filter-sterilized and added to sterile agar as follows concentrations: $\mathrm{CdCl} 2,10-50 \mu \mathrm{g} / \mathrm{ml} ; \mathrm{AlCl} 3,400-500$ $\mu \mathrm{g} / \mathrm{ml} ; \mathrm{HgCl} 2,50-100 \mu \mathrm{g} / \mathrm{ml} ; \mathrm{MnCl} 2,500-600 \mu \mathrm{g} / \mathrm{ml}$ and $\mathrm{ZnCl} 2,50-100 \mu \mathrm{g} / \mathrm{ml}$.

\section{Results}

\subsection{Root and Epicotyls Endophytic Bacteria}

The isolation of endophytic bacteria from the vegetative organs of Carob seedlings harvested after six months of culture, in occurrence from roots and epicotyls, was very successful. However, the presence of bacteria in the two organs was not found with plants of all accessions, for instance: Taourirt and al-Houceima (Table 1). Strains isolated from roots were coded as IRC (Isolates Root Carob) and similarly strains isolated from epicotyls were coded IEC (Isolates Epicotyle Carob).

A total of 73 endophytic bacteria were isolated from roots (IRC) and were obtained from 9 accessions. The high numbers of these endophytes were obtained from Taounate accession with $26 \%$ of isolates and from Ouazane accession with $20.5 \%$ of isolates. The lowest number was recorded from Akchort accession with $1.4 \%$ of isolates.

11 endophytic bacteria were isolated from epicotyls and were obtained with plants originating from 3 accessions. More than $50 \%$ of isolates were obtained from Sidi Bou Othaman accession while $9.1 \%$ were native to Essaouira (Table 1).

Table 1. Percentage of endophytic bacteria isolated from roots and epicotyls of Carob seedlings originating from different regions of Morocco.

\begin{tabular}{|c|c|c|c|c|c|}
\hline Accession & Accession origin & Presence of endophytic bacteria (+) or (-) & Type of organ & $\%$ of IRC & $\%$ of IEC \\
\hline 1 & Taourirt & - & - & - & - \\
\hline 2 & Al Houceima & - & - & - & - \\
\hline 3 & Taounate & + & $\begin{array}{l}\text { Roots } \\
\text { Epicotyls }\end{array}$ & 26 & 36.4 \\
\hline 4 & Aïn Safa & + & Roots & 5.5 & 0 \\
\hline 5 & Akchort & + & Roots & 1.4 & 0 \\
\hline 6 & Demnate & + & Roots & 9.6 & 0 \\
\hline 8 & Sidi Bou Othmane & + & $\begin{array}{l}\text { Roots } \\
\text { Epicotyls }\end{array}$ & 4.1 & 54.5 \\
\hline 9 & Essaouira & + & $\begin{array}{l}\text { Roots } \\
\text { Epicotyls }\end{array}$ & 4.1 & 9.1 \\
\hline 10 & Tétouan & + & Roots & 16.4 & 0 \\
\hline 11 & Ouad Laou & + & Roots & 12.4 & 0 \\
\hline Total & 11 & 73 from roots 11 from epicotyls & & 100 & 100 \\
\hline
\end{tabular}

The dendrogram (PCR-Rep) constructed on pair-wise comparison of Rep fingerprints of all IRC, IEC and RCM strains, showed a high diversity (data not shown). In fact, we obtained 8 clusters and 18 independent lineages above $85 \%$ of similarity level. The results allowed us to identify the exact number of strains in our collection. We obtained 65 different strains for root endophytes and only 3 strains for epicotyls endophytes. 30 IRC and 4 IEC strains representing the various groups were selected for the further analyses.

\subsection{Phenotypic Features}

42 strains originating from Carob, the 34 endophytic bacteria (30 IRC and 4 IEC) selected on the basis of Rep analysis and the 8 symbiotic bacteria RCM, were used in four phenotypic tests.

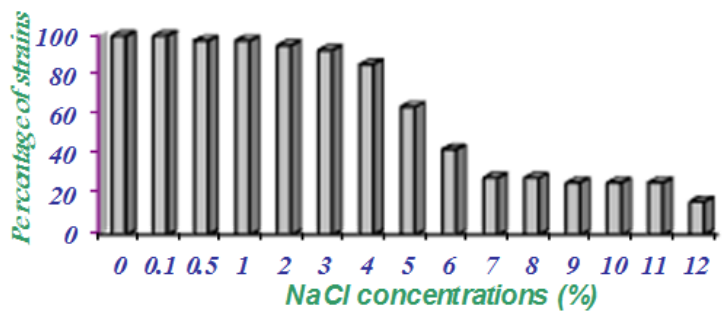

Figure 2. Tolerance of Carob strains to different concentrations of $\mathrm{NaCl}$.
Salt tolerance: Figure 2 shows that all the strains exhibited a clear tolerance to the salt tested. More than $90 \%$ of strains grew well from 1 to $3 \% \mathrm{NaCl}$. At higher concentration, the percentage of tolerant strains decreased. However, more than $60 \%$ were tolerant to $5 \% \mathrm{NaCl}$ and about $30 \%$ were tolerant to $11 \% \mathrm{NaCl}$.

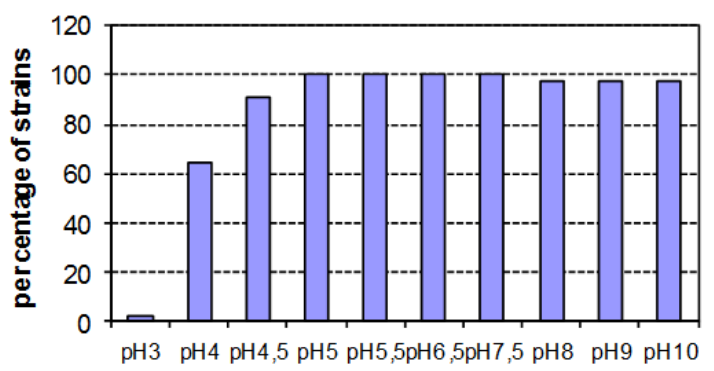

Figure 3. Tolerance of Carob strains to different $\mathrm{pH}$.

pH tolerance: All the tested bacteria were uniformly tolerant to the variable $\mathrm{pH}$ tested (Figure 3). $90 \%$ of strains grew well in slightly acid and acid pH. $60 \%$ of strains were acid-tolerant exhibiting a marked tolerance at $\mathrm{pH} 4$. However, at $\mathrm{pH} 3$, most the strains were sensitive. In alkaline $\mathrm{pH}$, strains were widely tolerant.

Antibiotics resistance: More than $60 \%$ of strains exhibited a 
high resistance to the concentration of $10 \mu \mathrm{l} / \mathrm{ml}$ of ampicillin, chloramphenicol, erythromycin, nalidixic-acid, spectinomycin and streptomycin while a lower percentage was recorded with kanamycin and tetracycline. This result was highly observed with the other concentrations tested (50 and $100 \mu \mathrm{g} / \mathrm{mL}$ ). The latest two antibiotics have significantly affected the growth of the bacteria. However, nalidixic acid produce a slight inhibitory effect on the growth of the different strains (Table 2).

Table 2. Effect of different antibiotics on growth of Carob endophytic bacteria and RCM strains.

\begin{tabular}{|c|c|c|c|c|c|c|c|c|c|c|c|c|c|c|c|c|c|c|c|c|c|c|c|c|c|c|c|}
\hline \multirow{2}{*}{ Souche } & \multicolumn{3}{|c|}{ Strep } & \multicolumn{3}{|c|}{ Spect } & \multicolumn{3}{|c|}{ Amp } & \multicolumn{3}{|c|}{ Rif } & \multicolumn{3}{|c|}{ Kan } & \multicolumn{3}{|c|}{ Chlo } & \multicolumn{3}{|c|}{ Ac. Nal } & \multicolumn{3}{|c|}{ Ery } & \multicolumn{3}{|c|}{ Tet } \\
\hline & 1 & 2 & 3 & 1 & 2 & 3 & 1 & 2 & 3 & 1 & 2 & 3 & 1 & 2 & 3 & 1 & 2 & 3 & 1 & 2 & 3 & 1 & 2 & 3 & 1 & 2 & 3 \\
\hline IRC1 & + & + & + & + & + & + & - & - & - & + & + & - & + & + & - & + & + & + & + & + & + & - & - & - & - & - & - \\
\hline IRC6 & + & + & + & + & + & + & + & + & + & + & + & + & + & + & + & + & + & + & + & + & + & - & - & - & - & - & - \\
\hline IRC7 & + & + & + & + & + & + & + & + & + & + & + & + & + & - & - & + & + & + & + & + & + & + & + & + & - & - & - \\
\hline IRC9 & + & + & + & + & + & - & + & + & + & + & + & + & + & + & + & + & + & + & + & + & + & + & + & + & - & - & - \\
\hline IRC11 & + & + & + & + & + & + & + & + & + & + & + & + & + & + & - & + & + & + & + & + & + & + & + & + & - & - & - \\
\hline IRC15 & + & + & + & + & + & + & + & + & - & + & + & + & + & - & - & + & + & + & + & + & + & + & + & + & - & - & - \\
\hline IRC18 & + & + & - & + & + & + & + & + & + & + & + & + & - & - & - & + & + & + & + & + & + & + & + & + & + & - & - \\
\hline IRC19 & + & + & + & + & + & + & + & + & + & + & + & + & + & + & - & + & + & + & + & + & + & + & + & + & - & - & - \\
\hline IRC20 & + & + & + & + & + & + & + & - & - & + & + & + & + & - & - & + & + & + & + & + & + & + & + & + & - & - & - \\
\hline IRC24 & + & - & - & + & + & + & - & - & - & - & - & - & + & - & - & + & + & - & + & - & - & - & - & - & + & - & - \\
\hline IRC27 & + & + & - & + & + & + & + & + & + & - & - & - & - & - & - & + & + & - & - & - & - & - & - & - & + & - & - \\
\hline IRC29 & + & - & - & + & + & + & + & + & + & + & - & - & - & - & - & + & + & - & + & + & + & - & - & - & + & + & - \\
\hline IRC32 & + & - & - & + & - & - & + & + & + & - & - & - & - & - & - & - & - & - & - & - & - & - & - & - & - & - & - \\
\hline IRC37 & + & + & + & + & + & + & + & + & + & + & + & + & + & + & - & + & + & + & + & + & + & + & + & + & - & - & - \\
\hline IRC42 & - & - & - & - & - & - & - & - & - & - & - & - & - & - & - & - & - & - & - & - & - & - & - & - & - & - & - \\
\hline IRC43 & - & - & - & + & + & + & - & - & - & - & - & - & - & - & - & - & - & - & - & - & - & - & - & - & - & - & - \\
\hline IRC44 & + & + & + & + & + & + & + & + & + & - & - & - & + & - & - & + & + & - & + & + & - & - & - & - & + & + & + \\
\hline IRC45 & - & - & - & + & - & - & - & - & - & + & + & + & - & - & - & + & - & - & - & - & - & - & - & - & - & - & - \\
\hline IRC47 & - & - & - & + & - & - & + & - & - & - & - & - & - & - & - & - & - & - & - & - & - & - & - & - & - & - & - \\
\hline IRC49 & + & + & - & + & - & - & + & + & + & + & + & + & + & - & - & + & + & + & + & + & + & + & + & + & + & + & - \\
\hline IRC50 & - & - & - & + & + & + & - & - & - & - & - & - & - & - & - & + & - & - & - & - & - & - & - & - & + & - & - \\
\hline IRC51 & + & - & - & + & - & - & + & + & + & + & + & + & + & - & - & + & + & + & + & + & + & + & + & + & + & + & - \\
\hline IRC53 & + & + & + & + & + & + & + & + & + & + & + & + & + & + & + & + & + & + & + & + & + & + & + & + & + & + & + \\
\hline IRC54 & + & + & + & + & + & + & + & + & + & + & + & + & + & + & + & + & - & - & + & + & + & + & - & - & + & - & - \\
\hline IRC56 & + & + & + & + & + & + & + & + & + & + & + & + & + & + & - & + & + & + & + & + & + & + & + & + & - & - & - \\
\hline IRC57 & + & + & + & + & - & - & + & - & - & - & - & - & + & - & - & + & + & + & + & - & - & + & + & + & - & - & - \\
\hline IRC58 & + & - & - & + & - & - & + & + & - & - & - & - & - & - & - & - & - & - & - & - & - & - & - & - & - & - & - \\
\hline IRC61 & - & - & - & + & - & - & - & - & - & - & - & - & - & - & - & - & - & - & - & - & - & - & - & - & - & - & - \\
\hline IRC66 & - & - & - & + & - & - & + & - & - & + & + & - & - & - & - & - & - & - & + & + & + & - & - & - & - & - & - \\
\hline IRC73 & - & - & - & + & - & - & - & - & - & - & - & - & - & - & - & + & + & + & + & + & + & + & - & - & - & - & - \\
\hline IEC 1 & + & + & + & + & + & + & + & + & + & + & + & - & + & + & + & + & + & + & + & + & + & + & + & + & - & - & - \\
\hline IEC4 & + & + & + & + & + & + & + & + & + & + & + & + & + & + & - & + & + & + & + & + & + & + & + & + & - & - & - \\
\hline IEC10 & - & - & - & - & - & - & - & - & - & - & - & - & - & - & - & + & - & - & + & + & - & - & - & - & - & - & - \\
\hline IEC11 & + & + & + & + & + & + & + & + & - & + & + & + & + & + & - & + & + & + & + & + & + & + & + & + & - & - & - \\
\hline RCM3 & + & - & - & + & + & + & + & + & + & + & + & + & - & - & - & + & + & + & + & + & + & + & + & + & + & - & - \\
\hline RCM4 & + & + & - & + & + & + & + & + & + & + & + & + & - & - & - & + & + & + & + & + & + & + & + & + & + & - & - \\
\hline RCM5 & - & - & - & - & - & - & - & - & - & - & - & - & - & - & - & + & + & - & - & - & - & + & + & + & - & - & - \\
\hline RCM7 & + & + & - & + & + & + & + & + & + & + & + & + & - & - & - & + & + & + & + & + & + & + & + & + & + & + & - \\
\hline RCM9 & + & + & + & + & + & + & + & + & + & + & + & + & + & + & + & + & + & + & + & + & + & + & + & + & - & - & - \\
\hline RCM10 & - & - & - & - & - & - & - & - & - & + & + & + & - & - & - & - & - & - & + & - & - & - & - & - & - & - & - \\
\hline RCM11 & + & + & + & + & + & + & + & + & + & + & + & + & + & + & + & + & + & + & + & + & + & - & - & - & - & - & - \\
\hline RCM12 & + & + & - & + & - & - & - & - & - & + & + & + & + & + & - & + & + & + & + & + & + & + & + & + & - & - & - \\
\hline
\end{tabular}

1: correspond to $10 \mu \mathrm{g} / \mathrm{ml}$. 2: correspond to $50 \mu \mathrm{g} / \mathrm{ml}$. 3: correspond to $100 \mu \mathrm{g} / \mathrm{ml}$. (+): resistance. (-): sensible

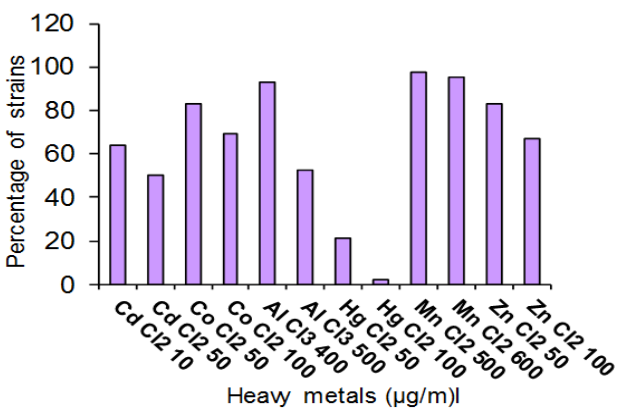

Figure 4. Effect of heavy metals on the growth of Carob associative bacteria.
Heavy metal resistance: The Carob associated bacteria showed a wide resistance to heavy metals tested (Figure 4). Except for a few number (18\%), all the strains were sensitive to mercury chloride. The others metals (cadmium, cobalt, aluminium, manganese and zinc), were less toxic on the growth of bacteria even at a higher concentration of $500 \mu \mathrm{g} / \mathrm{ml}$. Manganese is the least toxic metal because even at very high concentrations, the growth of the strains were not affected. The aluminum concentration of $500 \mu \mathrm{g} / \mathrm{ml}$ inhibited half of the strains. For cobalt and zinc, more than $60 \%$ of strains were resistant to a concentration of $100 \mu \mathrm{g} / \mathrm{ml}$. For cadmium, $65 \%$ of strains were resistant to a concentration of $50 \mu \mathrm{g} / \mathrm{ml}$ and the half 
of the strains to $100 \mu \mathrm{g} / \mathrm{ml}$.

\section{Discussion}

The present study demonstrates clearly that associative endophytic bacteria can reside in the internal tissues of the vegetative organs, in occurrence epicotyls and roots of Carob without inducing any obvious symptoms. Plants grown in natural soil eventually develop a continuum associative relationship with living microorganisms that can extend from the rhizosphere to the rhizoplane, deeply into the epidermis, the endodermis and through the vascular system [25, 34]. The endophytic habitat has been reported as an important pool for the isolation of $\mathrm{N}$-fixing plant growth-promoting rhizobacteria [45]. The plant naturally select endophytes that can fit competitively to occupy compatible niches within its nutritionally-enriched and protected habitat of its internal tissues without causing pathological symptoms on the host plant [46].

Several authors reported the capacity of different bacteria to infect and colonize roots, stems, leaves or the system vascular of a wide range of monocotyledons and dicotyledons. In fact, many plants such as Saccharum officinarum [20, 47], Sorghum bicolor L. [48], Triticum aestivum [33, 49], Oryza sativa L. [33, 34, 50, 51], Zea mays L. [28, 52], Gossypium sp. [53, 54], Vitis vinifera [25, 55], Lactuca sativa [28], Picea -abies [56], Coffea arabica [57], Helianthus petiolaris [11], Musa spp. and Ananas comosus L. [58] are successively reported to establish beneficial association with different type of endophytic bacteria. This could strongly contribute to increase productivity and reduce disease in the agricultural practices in regard to the potential of these bacteria concerning their reaction to mineral concentration and antibiotics.

Roots and epicotyls endophytes were found with all plant accessions, except Al Houceima and Taourirt. A total of 73 endophytic bacteria was isolated. Most of the isolates originated from roots especially from Taounate and Oauzane accessions. However, 11 endophytic bacteria were isolated from epicotyls and were obtained only from three accessions. In Vietnam, 561 endophytic bacteria were isolated from stems and roots of 70 Rice plants [51].

PCR-Rep allowed us to determine the exact number of the different endophytes in the collection. Root endophytes showed to be more diverse than expected with a number of 65 strains while, epicotyls endophytes were represented by 3 distinct strains.

34 rep-based selected strains, for instance IEC and IRC, and 8 RCM strains were subject of three physiologic tests. Morphologically, Carob endophytic bacteria were found to be Gram-negative, non-spore-forming, motile and rods. The optimum temperature was $28-30^{\circ} \mathrm{C}$. The colonies were circular, convex, smooth, raised, and mucilaginous, usually 2 $-4 \mathrm{~mm}$ in diameter within $3-5$ on YEM medium. Strains exhibited a wide tolerance to salinity $(\mathrm{NaCl}) .15 \%$ of strains showed a great osmotolerance since they were able to grow in $12 \% \mathrm{NaCl}$. It was reported that Bacillus endophyticus sp. isolated from the internal tissues of cotton plants (Gossypium sp.) presented an optimum growth in the presence of $10 \%$ $\mathrm{NaCl}$ [54]. Rhizobia isolated from woody legumes like Hedysarum, Acacia, Prosopis and Leucaena can also tolerate high $\mathrm{NaCl}$ concentrations up to 500 and $800 \mathrm{mM} \mathrm{NaCl}$ [59]. A strong salt tolerance was reported to aid in tolerance to high $\mathrm{pH}$ and temperature [60]. Many species of rhizobia were reported to develop adaptation to salinity stress by intracellular accumulation of compatible solute [61]. Salt tolerance strains can give them advantages to survive, multiply in saline soil and efficiency infect their host plants. Strains were uniformly tolerant to high $\mathrm{pH}$. At low $\mathrm{pH}, 60 \%$ of strains exhibited an acid-tolerant character since they grew well at $\mathrm{pH}$ 4. Some physiological studies showed that Gluconacetobacter diazotrophicus, endophyte of sugarcane, grew well at $\mathrm{pH} 5.5$ and was able to grow at $\mathrm{pH} 3.0$ and even to fix nitrogen in a culture medium at $\mathrm{pH} 2.5$ [62]. Spirillum lipoferum, endophyte of Digitaria, has an optimum growth and Nitrogen fixing capacity at $\mathrm{pH} 6.8$ to 7.8 [63]. Various rhizobial strains such as $R$. tropici, R. leguminosarum bv. trifolii and Mesorhizobium loti, were described as acid-tolerant and presented a good growth at $\mathrm{pH} 4[64,65,66]$.

Strains were highly sensitive to tetracyclin and to kanamicin. But they were mostly resistant to nalidixic acid. They showed, however, a similar character in their resistance to the different concentrations tested of ampicillin, chloramphenicol, erythromycin, Nalidixic acid, spectinomycin and streptomycin. This result, indicate that strains exhibited a multiple antibiotic resistance. The same result was described for many rhizobacteria. Various strains belonging to the genus Burkholderia such as B. vietnamiensis isolated from rice exhibited a multiple antibiotic resistance [26]. Schwinghamer [67] and Cole et al. [68] has described several strains of Rhizobium sp., resistants to several antibiotics. The rhizobia isolated from root-nodule of Cicer arietinum grew well in presence of 9 different antibiotics [66].

The level of heavy metal resistance exhibited by Carob associative bacteria, appears relatively high compared to what we know in general on rhizobia. Their resistance to metals is very similar to the behavior of rhizobium strains nodulating Acacia sp. [69], and slightly different from that exhibited by strains of rhizobia isolated from Cicer arietinum (64). In general, compared to various species of rhizobia, the endophytic bacteria from roots and epicotyls of Carob as well as those of the RCM collection exhibited good tolerance to heavy metals. This feature can be exploited later in the bioremediation trials aimed at improving the quality of soil contaminated with heavy metals sites.

\section{Conclusion}

We clearly demonstrate that rhizobacteria possess the faculty that allow them to be associate efficiently as natural endophytes with Carob tree (Ceratonia siliqua L.). So, our study, confirm the result obtained by Bryan et al. [22] who observed the enzyme Nitrogen-fixing activities in Carob roots and bourgeons internal for in vitro culture. Under laboratory conditions, the direct isolation of associative endophytic 
bacteria, from vegetative organs of Carob, was successfully positive. 73 and 11 isolates were respectively recovered from roots and epicotyls of plants originating from eleven different regions of Morocco. Rep analysis showed a high level of diversity. The strains selected by Rep marker grew well in YEM alkaline medium and were also acid-tolerant. They were mostly osmotolerant and exhibited a multiple antibiotic and heavy metal resistances. These results could serve as a reference for future ecosystems management.

\section{Acknowledgements}

This work was realized in the LMMB (Morocco). It was supported by the Moroccan project PROTARS I-P2T2/24 and by the IRD project No 01-2-MAR-28-1.

\section{References}

[1] Hill, G. T., N. A. Mitkowski, L. Aldrich-Wolfe, L. R. Emele, D. D. Jurkonie, A. Ficke, S. Maldonado-Ramirez, S. T. Lynch and E. B. Nelson. 2000. Methods for assessing the composition and diversity of soil microbial communities. Appl. Soil Microbiol. 15: $25-36$.

[2] Haiiman, J., A. Quadt-Hallman, W. F. Mahafee, and J. W. Kleopper. 1997. Bacterial endophytes in agricultural crops. Can. J. Microbiol. 43: 895- 914.

[3] Sturz, A. V., and Nowak. 2000. Endophytic communities of rhizobacteria and the strategies required to create yield enhancing associations with crops. Ecol Appl. Soil. 15: 183- 190.

[4] Jacobs, M. J., W. M. Bugdee, and D. A. Gabrielson. 1985. Enumeration, location, and characterization of endophytic bacteria within sugar-beet roots. Can. J. Bot. 63: 1262- 1265.

[5] De Bary A. 1866. Morphologie und physiologie der Pilze, Flechten und Myxomyceten. Hofmeister's Handbook of Physiological Botany, Vol. 2, Leipzig

[6] Stone, J. K. 1986. Foliar endophytes of Pseudotsugamenziesli (Mirb) Franco. Cytology and physiology of the host-endophyte relationship. DSc Thesis, Univ. of Oregon, Eugene, Canada.

[7] Baldani, J. I., and V. L. D. Baldani. 2005. History on the biological nitrogen fixation research in graminaceous plants: special emphasis on the Brazilian experience. An. Acad. Bras. Cienc. 77: 549- 579.

[8] Petrini, O. 1991. Fungal endophytes of tree leaves. In:Andrews J. and Hirano (Eds), Microbial ecology of leaves. New York: Springer Verlag, p. 179- 197.

[9] Kloepper, J. W., R. M. Zablotowicz, E. M. Tipping, R. Lifshitz. 1991. Plant growth promotion mediated by bacterial rhizosphere colonizers. In: Keister, D. L., Cregow, P. B. (Eds), The rhizosphere and plant growth. Kluwer Academic Publishers, Dordrecht, pp. 315-326.

[10] Lazarovits, G., and J. Nowak. 1997. Rhizobacteria for improvement of plant growth and establishment. HortScience 32: 188-192.

[11] Alami, Y., W. Achouak, C. Marol, and T. Heulin. 2000. Rhizosphere soil aggregation and plant growth promotion of Sunflowers by an exopolysaccharide-producing Rhizobium sp. strain isolated from Sunflower roots. Appl. Environ. Microbiol. 66: 3393-3398.

[12] Chen, C., E. M. Bauske, G. Musson, R. Rodriguez-Cabaña, J. Kloepper. 1995. Biological control of Fusarium on cotton by use of endophytic bacteria. Biolo. Control. 5: 83-91.

[13] Lodewyckx, C., J. Vangrosveld, F. Portteous, E. R. B. Moore, S. Taghavi, M. Mezgeay, and D. van der Lelie. 2002. Endophytic bacteria and their potential applications. Crit. Rev. Plant Sci. 21: 583-606.

[14] Scroth, M. N., and J. G. Hancock. 1981. Selected topics in biological control. An. Rev. Microbiol. 35: 453-476.

[15] Weller, D. M. 1988. Biological control of soil-borne plant pathogens in the rhizosphere with bacteria. An. Rev. Phytopathol. 26: 379-407.

[16] Webster, G., V. Jain, M. R. Davey, C. Gough, J. Vasse, J. Dénarié, and E. C. Cocking. 1998. The flavonoid naringenin stimulates the intercellular colonization of wheat roots by Azorhizaobium caulinodans. Plant Cell and Environ. 21: 373-383.

[17] Gough, C., C. Galera, J. Vasse, G. Webster, E. C. Cocking and J. Dénarié. 1997a. Specific flavonoids promote intercellular root colonization of Arabidopsis thaliana by Azorhizobium caulinodans ORS571. Mol. Plant-Interac. 10: 560-570.

[18] Ndoye, I., F. De Billy, J. Vasse, B. Dreyfus, and G. Truchet. 1994. Root nodulation of Sesbania rostrata. J. of Bacteriol. 176: 1060-1068.

[19] Patriquin, D. G., J. Döbereiner, and D. K. Jain. 1983. Sites and processes of association between diazotrophs and grasses. Can J. Microbiol. 29: 900-915.

[20] Boddey, R. M., O. C. De Oliveira, S. Urquiagea, V. M. Reis, F. L. De Olivares, V. L. D. Baldani, and J. Doebereiner. 1995. Biological nitrogen fixation associated with sugarcane and rice: contribution and prospects for improvement. Plant Soil 174: 195-209.

[21] Urquiaga, S., K. H. S. Cruz, and R. M. Boddey. 1992. Contribution of nitrogen fixation to sugar cane: nitrogen-15 and nitrogen-balance estimates. Soil Sci. Soc. Am. J. 56: 105-114.

[22] Bryan J.A., Berlyn G. P. And Gordon J.C. 1996. Towards a new concept of the evolution of symbiotic nitrogen fixation in the Leguminosae. Plant Soil, 186: 151-159.

[23] Bormann, F. H., G. E. Likens, and J. M. Melillo. 1980. Nitrogen budget for an aggrading northern hardwood forest ecosystem. Sciences. 196: 981-983.

[24] Reinhold-Hurek, B., and T. Hurek. 1998. Life in grasses: diazorophic endophytes. Trends Microbiol. 6: 139-144.

[25] Compant, S., B. Reiter, A. Sessistsch, J. Nowak, C. Clément, and E. A. Barka. 2005. Endophytic colonization of Vitis vinifera L. by palnt growth-promoting bacterium Burkholderia sp. strain PsJN. Appl. Environ. Microbilo. 71: 1685-1693.

[26] Gillis M., T. Tran van, R. Bardin, M. Goor, P. Herbar, A. Willems, P. Segers, K. Kersters, T. Heulin, and M. P. Fernandez. 1995. Polyphasic taxonomy in the genus Burkholderia leading to an emended description of the genus and preposition of Burkholderia vietnamiensis sp. nov., for $\mathrm{N}_{2}$-fixing isolates from rice in Vietnam. Int. J. Syst. Evol. Microbiol. 45: 274-289. 
[27] Reinhold-Hurek, B., and T. Hurek, M. Gillis, B. Hoste, M. Vancanneyt, K. Kersters, and J. De Ley. 1993b. Azoarcus gen. nov., nitrogen-fixing proteobacteria associated with roots of Kallar grass (Leptochloa fusca (L.) Kunth) and description of two species Azoarcus indigens sp. nov. and Azoarcus communis sp. nov. Int. J. Syst. Bacteriol. 43: 574-584.

[28] Chabot, R., H. Antoun, J. W. Kloepper, and C. J. Beauchamp. 1996. Root colonization of Maize and Lettuce by Bioluminescent Rhizobium leguminosarum biovar phaseoli. Appl. Environ. Microbiol. 62: 2767-2772.

[29] Chaintreuil, C., E. Giraud, Y. Prin, J. Lorquin, A. Bâ, M. Gillis, P. De Lajudie, and B. Dreyfus. 2000. Photosynthetic Bradyrhizobia are natural endophytes of the african wild rice Oryza breviligulata. Appl. Environ. Microbiol. 66: 5437-5447.

[30] Chi, F., S. H. Shen, H. P. Cheng, Y. X. Jing, Y. G. Yanni, and F. B. Dazzo. 2005. Ascending migration of endophytic Rhizobia, from roots to leaves, inside rice plants and assessment to benefits to rice growth physiology. Appl. Environ. Microbiol. 71: 7271-7278.

[31] Matiru, V. N., and F. D. Dakora. 2004. Potential use of rhizobial as promoters of plant growth for inceased yield in landraces of African cereal crops. Afr. J. Biotechnol. 3: 1-7.

[32] O'Callaghan, K. J., M. R. Davey, and E. C. Cocking. 1997. Xylem colonization of the legume Sesbania rostrata by Azorhizobium caulinodans. Proc. R. Soc. Lond. B. 264: 1821-1826.

[33] Webster, G., C. Gough, J. Vasse, C. A. Batchelor, K. J. O'Callaghan, S. L. Kothari, M. R. Davey, J. Dénarié, and E. C. Cocking. 1997. Interaction of rhizobia with rice and wheat. Plant Soil. 194: 115-22.

[34] Yanni Y. G., R. Y. Rizk, V. Corich, A. Squartini, K. Ninke, S. Philip-Hollingsworth, G. Orgambide, F. De Buijn, R. Stoltzfus, D. Buckley, T. Schmidt, P. F. Mateos, J. K. Ladha, and F. B. Dazzo. 1997. Natural endophytic association between Rhizobium leguminosarum bv. Trifolii and rice roots and assessment of its potential to promote rice growth. Plant Soil. 194: 99-114.

[35] Koulibaly, A., D. Goetze, S. Porembski and L. Aké-Assi. 2010. Vegetation characteristics and changes under cash crop cultivation in forest-savanna mosaics in Côte d'Ivoire. In: X van der Burgt, J. van der Maesen \& J.M. Onana (eds), Systematics and Conservation of African Plants. Roval Botanic Gardens, Kew, pp. 805-814.

[36] Kebe I.B., Mpika J., N'Guessan K.F., Hebbar P.K., Samuels G.S. and Ake S. 2009. Isolement et identification de microorganisms indigenes de cacaoyères en Côte d'Ivoire et mise en evidence de leurs effets antanistes vis-vis de Phytosphtora palmivora, agent de la pourriture brune des cabosses. Sciences \& Nature, 6 (1) : 71-82.

[37] Christodoukakis, N. S. 1992. Structural diversity and adaptation in some Mediterranean evergreen sclerophyllous species. Environ. Experment. Bot. 32: 295- 305.

[38] Batlle, I., and J. Tous. 1997. Carob tree (Ceratonia siliqua L.), promoting the conservation and use of under utilized and neglected crops. 17, Institute of Plant Genetic and Crop Plant Research, Galersleben/International Plant Genetics Resources Institute, Rome.

[39] Hamed, T. E., A. Ezzat, and S. Y. Al-Okbi. 2003. Therapeutic diets for diarrhea: Biological evaluation in Rats. Pak. J. Biol.
Sci. 6: $1501-1508$.

[40] Loed, H., Y. Vandenplas, P. Wursch, and P. Guesry. 1989. Tannin-rich Carob pad for the treatment of acute-onset diarrhea. J. Pediatr Gastroentrol Nutr. 8: 480.

[41] Yatzidis, H. 1980. Traitement de l'insuffisance rénale chronique par la gomme de caroube. Nouvelle Presse Méditerranéenne. 9: 3065.

[42] Konate I., E.B. Berraho and A. Filali-Maltouf. 2009. Inter-Simple Sequence Repeat Markers Variation among Natural Accessions of Moroccan Carob Tree (Ceratonia siliqua L.), International Journal of Agriculture and Biology, 11: 168-172.

[43] Vincent, J. M. 1970. A manual for the practical study of root nodule bacteria. IBP (Int. Biol. Programme) Handbook 15 Blackwell, Scientific Publcations. Ltd. Oxford.

[44] Missbah M. E. I., A. Aujjar, A. Belabed, Y. Dessaux, and A. Filali-Maltouf. 1996. Characterization of rhizobia isolated from Carob (Ceratonia siliqua). J. Appl. Bacteriol. 80: 165-173.

[45] Shenoy, V. V., G. M. Kalagudi, and B. V. Gurudatta. 2001. Towards nitrogen autotrophic rice. Curr. Sci. 81: 451-457.

[46] Kleopper, J. W., and C. J. Beauchamp. 1992. A review of issues related to measuring colonization of plant roots by bacteria. Can. J. Microbiol. 38: 1219-1232.

[47] Gillis M., K. Kerskers, B. Hoste, D. Janssens, R. M. Krosppenstedt, M. P. Stephan, K. R. S. Teixeira, J. Döbereiner, and J. De Ley. 1989. Acetobacter diazotrophicus sp. nov., a nitrogen-fixing acetic acid bacterium associated with sugarcane. Int. J. Syst. Bacteriol. 39: 361- 364.

[48] James, E. K., F. L. Olivares, J. I. Baldani, and J. Dödereiner. 1997. Herbaspirillum an endophytic diazotroph colonizing vascular tissue in leaves of Sorghonum bicolor L. Moench. J. Exp. Bot. 48: 785- 797.

[49] Sabry, S. R. S., S. A. Saleh, C. A. Batchelor, J. Jones, J. Jotham, G. Webster, S. L. Kothari, M. R. Davey, and E. C. Cocking. 1997. Endophytic establishment of Azorhizobium caulinodans in wheat. Proceding of the Royal Society, London: Biological Sciences. 264: 341- 346.

[50] Christiansen-Weniger, C. 1996. Endophytic establishment of Azorhizobium caulinodans through auxin-induced root tumours of rice (Oryza sativa L.). Biol. Fert. Soil. 21: 293- 302.

[51] Van Thi P. N and Cao Ngoc D. 2014. Isolation, characterization and phylogenetic analysis of endophytic bacteria in rice plant cultivated on soil of Phu Yen provence, Vietnam. American Journal of Life Sciences. 2 (3): 117-127.

[52] Seghers, D., L. Wittebolle, E. M. Top, W. Verstraete, and S. D. Siciliano. 2004. Impact of agricultural practise on the Zea mays L. endophytic community. Appl. Environ. Microbiol. 70: 1475-1482.

[53] Misaghi, I. J., and C. R. Donndelinger. 1990. Endophytic bacteria in symptom-free cotton plant. Phytopathology. 9: 808-811.

[54] Reva, O. N., V.V. Smirnov, B. Pettersson, and F. G. Priest. 2002. Bacillus endophyticus sp. nov., isolated from the inner tissues of cotton plants (Gossypium sp.). Int. J. Syst. Microbiol. 52: 101-107. 
[55] Bell, C. R., G. A. Dickie, W. L. G. Harvey, and J. W. Y. F. Chan. 1995. Endophytic bacteria in grapevine. Can. J. Microbiol. 41: 46-53.

[56] Shishido, M., C. Breuil, and C. P. Chanway. 1999. Endophytic colonization of spruce by plant growth-promoting rhizobia. FEMS Microbiol. Ecol. 29: 191-196.

[57] Jimenez-Salgado, T., L. E. Fuentes-Ramirez, A. Tapia-Hernandez, A. M. Mascarua-Esperanza, E. Martinez-Romero, and J. Caballero-Mellado. 1997. Coffea arabica L. a new host for Acetobacter diazotrophicus and isolation of other nitrogen-fixing Acetobacteria. Appl. Environ. Microbiol. 63: 3676-3683.

[58] Cruz L. M., E. M. Souza, O. B. Weber, J. I. Baldani, J. Döbereiner, and F. O. Pedrosa. 2001. 16S rDNA characterization of nitrogen-fixing bacteria isolated from Banana (Musa sp.) and Pineapple (Ananas comosus (L.) Merril). Appl. Environ. Microbiol. 67: 2376-2379.

[59] Tilak, K. V. B. R., N. Ranganayaki, K. K. Pal, R. De, A. K. Saxena, C. S. Nautiyal, S. Mittal, A. K. Tripathi, and B. N. Johri. 2005. Diversity of plant growth and soil health supporting bacteria. Curr. Sci. 89: 136-150.

[60] Kulkarni, S. and C. S. Nautiyal. 2000. Effect of salt and pH stress on temperature-tolerant Rhizobium sp. NBRI330 nodulating Prosopis juliflora. Curr. Microbiol. 40: 221-226.

[61] Boncompagni, E., M. Osterås, M. Poggi, and D. Le Rudulier. 1999. Occurrence of choline and glycine betaine uptake metabolism in rhizobia. Appl. Environ. Microbil. 65: 2072-2077.
[62] Stephan, M. P., M. Oliveira, K. R. S. Texiera, G. Martinez-Drets, and J. Döbereiner. 1991. Physiology and dinitrogen fixation of Acetobacter diazotrophicus. FEMS Microbiol. Lett. 77: 67-72.

[63] Day, J. M., and J. Döbereiner. 1976. Physiological aspect of $\mathrm{N}_{2}$ fixation by a Spirillum from Digitaria root. Soil Biol. Biochem. 8: $45-50$.

[64] Cooper, J. E. 1982. Acid production, acid tolerance and growth rate of Lotus rhizobia in laboratory media. Soil Biol. Biochem. 14: 127-131.

[65] Graham, P. H., and C. A. Parker. 1994. Diagnostic features of the root-nodule bacteria of legumes. Plant Soil. 20: 383-396.

[66] Maâtallah, J., E. B. Berraho, J. Sanjuan, and C. Lluch. 2002. Phenotypic characterization of rhizobia isolated from chickpea (Cicer arietinum) growing in Moroccan soils. Agronomie. 22: 321- 29.

[67] Schwinghamer, E. A. 1967. Effectiveness of rhizobium as modified by mutation for resistance to antibiotics. Antonie van Leeuwenhoek. J. Microbiol. Serol. 33: 121-136.

[68] Cole, M. A., and G. H. Elkan. 1979. Multiple antibiotic resistance in Rhizobium japonicum. Appl. Environ. Microbiol. 37: 867-870.

[69] Mohammed S.H., A. Smouni, M. Neyra, D. Kharchef And A. Filali-Maltouf. 2000. Phenotypic characterization of root nodulating bacteria isolated from Acacia spp. Grown in Lybia. Plant Soil. 224: 171-183. 